\title{
Some Account Of The Keep Of Colchester Castle
}

\section{G. T. Clark}

To cite this article: G. T. Clark (1882) Some Account Of The Keep Of Colchester Castle, Archaeological Journal, 39:1, 239-256, DOI: 10.1080/00665983.1882.10852036

To link to this article: http://dx.doi.org/10.1080/00665983.1882.10852036

曲 Published online: 14 Jul 2014.

Submit your article to this journal $\pi$

Q View related articles $₫$ 
SOME ACCOUNT OF THE REEP OF COLCHESTER CASTLE.

By G. T. CLARK.

When Hubert of Rie, standing at early dawn between the church and his castle,

"Entre li moister e sa mote,"

welcomed, harboured, and under the escort of his three sons, sent forward his hard bested lord by the road still known as "Le Voye le Duc," he probably little thought that the incident would become matter of history, and still less could he have anticipated the splendid reward, for this and other faithful services, his sons were to receive, twenty years later, from that same soveriegn in a foreign and then unconquered land. Whether Hubert himself took part in the conquest is unknown: he certainly did not desert his mote and mostier in the Cotentin for any English possessions, but of his sons, Ralph and Adam received lands as under tenants in the counties of Nottingham, Derby, and Kent; and Eudo, called by Dugdale the fourth son, but the principal representative of the family in England, appears in the Survey as tenant in chief of 64 manors in the counties of Beds, Cambridge, Essex, Hants, Herts, Huntingdon, Lincoln, Norfolk, Northampton, and Suffolk.

Of these manors 25 were in Essex, in which county Eudo, entitled from his office "Dapifer," resided, and his possessions there lay in twelve of its twenty hundreds. In Colchester the lordship and demesne of the town were held by the king. Eudo's interest there was but moderate, consisting of five houses, 40 acres of land, and a claim to the fourth of certain lands held "in elemosina Regis." How he maintained his military position we are not told, or why he settled in Colchester. The only Essex castle mentioned in Domesday is Rageneia or Ralegh. "In hoc manerio fecit Suen suum castellum," nor do any of the old mottes, of which there are several, as Bures, 
Great Birch, Ongar, Plessy, and Stansted, appear to have belonged to Eudo. His office of Dapifer or Sewer he held under the Conqueror and his two successors, and he so witnessed a charter by William at Honfleur in 1074, and others by Rufus in 1093, and by Henry the First. Though described as "Dapifer Domini Regis totius Angliæe," he seems to have belonged to the ducal not the royal court, for the Sewer of England, according to Spelman, was the brother of Robert Fitz Hamon of Morganwg, who appears in the Survey in Colchester and elsewhere as "Hamo Dapifer." It is related that in consequence of the high character borne by Eudo the burgesses of Colchester moved William Rufus to place him in charge of their town. That he was so placed appears from a document quoted by Dugdale, and his connexion with the place is shewn by the Pipe Roll of 31 Henry I, in which, among other entries relating to Colchester, are items for "the lordship of the king's ploughlands of the land of Eudo Dapifer, 8s. .10d," and from "the farm of his land, paid into the treasury, $£ 91$ 3s. 0d." This was after Eudo's death, when Hamo de Clare was in charge. As the crown held the lion's share of the town, Eudo's position there must have been supreme. His first step was probably to build a castle, and upon his own land, for when in 1096 he founded St. John's Abbey, one of its endowments, specified in the foundation charter, was "omnes proventus capellae, in castello de Colcestria," which endowment is described in a confirmation by Richard the First ( 1 R. I) as " capellam castelli Colcestre, cum decimis et obventionibus," explained by Morant to have consisted in tythes of certain lands in and about the town.

Eudo's rank, as an Essex and Colchester land owner and the king's representative in the town, might very well induce him to erect a castle there. The position was a good one for a district destitute of any very striking inequalities of surface. It was within the Roman area, and covered on two sides by the Coln. The ancient wall, originally Roman, had been repaired by Edward the Elder, and included the town and the proposed site. A legendary document, quoted in the Monasticon [i, 724], states that Eudo built the castle 
on King Cole's foundation; “ in fundo palatii Coelis quondam regis," which may be taken to shew that there was an older building on the spot. If so it must have been Roman. Most of the chief towns in England contained a castle constructed long before the arrival of the Conqueror, though not a building of stone; and of these strong places the king or some great Norman baron usually availed himself, substituting, as occasion served, Norman masonry for the earlier and less perfect defences. Sometimes the castle was within the circuit of the town, as at Chichester, Chester, Leicester, and Lincoln, Roman cities with English additions; sometimes it was outside the town wall, but abutting upon it, as at Carlisle, Warwick, and Winchester. In each case the castle had its own proper defences, so that while, on the one hand, it could be held with the town against a common fue, on the other it could be held against the town, and used to overawe the citizens. Here the castle was placed within the Roman area, in its north-eastern quarter, and stood, not improbably, on the site of some considerable Roman building, to which the existing sewers are thought to have belonged.

Eudo died in 1120 at his castle of Preaux in Normandy, and was buried here at St. John's. He lived, therefore, twenty-four years after his religious foundation, and somewhat more than that time after the construction of his castle. He was also the founder, sometime in the reign of Henry the 1st, of the hospital of St. Mary Magdalen, in the suburbs of Colchester. He married Rohaise, whom Dugdale in his Baronage, citing Will. of Jumieges, calls the daughter of Walter Giffard, Earl of Buckingham, and widow of Fitz Gilbert, an error which, admitted into the earlier, is corrected in the later edition of the Monasticon, whence it appears that Rohaise was the daughter of Fitz Gilbert and a preceding Rohaise, and was married to Eudo in her nonage, "ante habiles annos nupta est." She laid the second stone of St. John's, Eudo himself laying the first. The issue of this marriage was Margaret, Eudo's sole heiress, who married William de Magnaville, and was mother of Geoffrey Earl of Essex, and in her right seneschal or sewer of Normandy. Geoffrey, who played his cards to great advantage 
between Stephen and the Empress Maud, received from the latter the lands of Eudo Dapifer in Normandy, with the office of Dapifer, and an option, under certain circumstances, of the lands of which Eudo died seized in England. These, however, he does not seem to have obtained; in the contemporary Pipe Rolls they are accounted for as in the Crown, and they do not appear in the Inquisitions on Geoffrey's descendants.

The castle, which from the endowment of its chapel must certainly have belonged to Eudo, came into the possession of the Crown. Morant cites a grant of it by Maud to Alberic de Vere, from an early edition of the Foedera (xiii, 251), but there is no such deed in the later or the latest edition. $\mathrm{He}$ also cites a deed in his own possession, of the reign of Richard or John, shewing that with other demesne manors the castle of Colchester and the Hundred were in the king's hands, and in the custody of the sheriff of Essex. In Stowe's Annals mention is made of a certain Hubert de St. Clare who warded off an arrow from Henry the First at the siege of Bridgenorth in 1165 at the cost of his own life, and whom Stowe calls Constable of Colchester, and adds that the king gave his daughter to William de Lanvalai. William, who was an Essex baron, certainly obtained the Constableship from King John ( $2 \mathrm{John}$ ), by a payment of 200 marcs. He died $12 \mathrm{John}$, leaving William his son, who was made Constable $17 \mathrm{John}$, but soon after joined the rebels. His daughter Hawise was afterwards given in wardship to Hubert de Burgh, who married her to his son John. King John visited the castle six times, in $1203,1205,1209,1212,1214$, and 1216 , staying three days during his two penultimate visits, and eleven days during his last visit. In 1214 Stephen Harengot was in charge in succession to Matthew Mantell ; also Hugh de Albemunt, carpenter, had an order for 23 marcs for work done, to which, in 1215, 20 marcs were added for repairs, and the burgesses were informed that Harengot was responsible for the king's rents. In April of that year Harengot was to have timber from a wood near the town, for its defence, "ad illam claudendam," and Hugh de Neville was to permit the same. In July, John's suspicious character led him to substitute for Harengot William de 
Lanvalai, who had married, as already stated, the daughter of a previous Constable. In this year the castle was besieged and taken by Saher de Quincy, who also burned the town. Both were afterwards recovered by King John.

In March, 1216, is recorded a list of one hundred and thirteen persons, knights, squires, and attendants, crossbowmen and foot-soldiers, from their names probably French mercenaries, to whom the king gave a safe conduct for a passage from the castle of Colchester to London. In April Harengot was again in charge, and in August he had a credit for 100 marcs out of a fine due of a thousand. This was for the payment of the garrison of the castle. In November, 1217, Richard de Mont Fitchet was ordered to give William, Bishop of London, seizin of Kingsworth wood belonging to the castle of Colchester, and to remove thence his own servants. In July, 1218, the king's bailiffs of Colchester were to respond for the farm of the town to the bishop, as they had used to do when Harengot held the castle. The bishop was at that time negociating for the king with the French invaders, who for a time actually held the castle. After John's death the bishop (Oct.: $2 \mathrm{H}$. III) had a credit on the farm of Colchester for $£ 20$ expended "in waristura" (munition) for the castle. In 1222 the sheriff of Essex, then in charge, was to transport certain timber, cut by the Constable of Dover Castle, to the port of Colchester. In January, 1223, the bailiffs of the town had credit from the exchequer for 100s. advanced by them to the constable of the castle. The Exchequer seems to have guarded the revenue closely, for in 1224 the Bishop of London is called upon to refund $£ 20$ paid to William, late Bishop of London, for the repairs of the king's castle of Colchester. In April, 1225, the Prud-hommes, "probi homines," of Colchester are to hand over the farm of the town to the constable for the repairs of the castle. The Bishop of London seems occasionally to have had charge, for in 1227 he is ordered to send to the king some person who may be trusted to deliver over the castle from the bishop to the king.

Hubert de Burgh seems at one time, with the wardship of Hawise de Lanvalai, to have held the Constable- 
ship of the castle; so that though not actually hereditary, some regard seems to have been had to descent. De Burgh was dispossessed in 1232, and was succeeded by Stephen de Segrave, and he by Thomas de Clare, who was constable in 1265-6, when 12 June, 1256, Henry the Third granted the castle and the fee-farm of the town to Guy de Montfort for life, he maintaining the castle in repair. He was one of Henry's unpopular foreign favourites, and was deprived in 1258. William de Wayland followed, who, 18 December, 1273, resigned it to John de Burgh, the last who held the office with any shadow of hereditary claim. In 1275 it was held by Richard de Holebrook, and immediately afterwards the castle became the county prison, in charge of the sheriff, and ceased to possess any military value. In 1347 some of the prisoners taken in France were lodged at Colchester; no doubt in the castle.

The constable of the castle was also steward of the hundred of Tendring, and bailiff of the same, holding courts for the several manors composing it. The castle was perfectly independent of the town, and like most castles so situated was extra-parochial, and had a separate jurisdiction. Seventeen manors were appendant to it, and paid suit and service at its court. In matters spiritual it was connected with St. John's. It appears from an Exchequer judgment in 1290, that the abbots of St. John, who received the tythes forming the endowment of the castle chapel, were wont to provide a chaplain, who celebrated the offices three days in each week, either in St. Helen's Chapel or in the King's Chapel in the castle, as the constable might direct. Long afterwards the abbot was fined 12 marcs for having neglected this duty. St. Helen's Chapel stood, and indeed, though desecrated, still stands about 100 yards N.E. of the keep, and just outside the line of the castle wall.

As the castle ceased to possess any military value it was from time to time granted away to various persons. Henry Duke of Lancaster, son of Henry IV, had it in 1404. Henry VI gave it to his queen, and Sir John Howard had it for life from Edward IV. In those days about 160 acres of land passed with the castle. In 1496-1509 it was held by John Earl of Oxford. Its final alienation was by James I, 


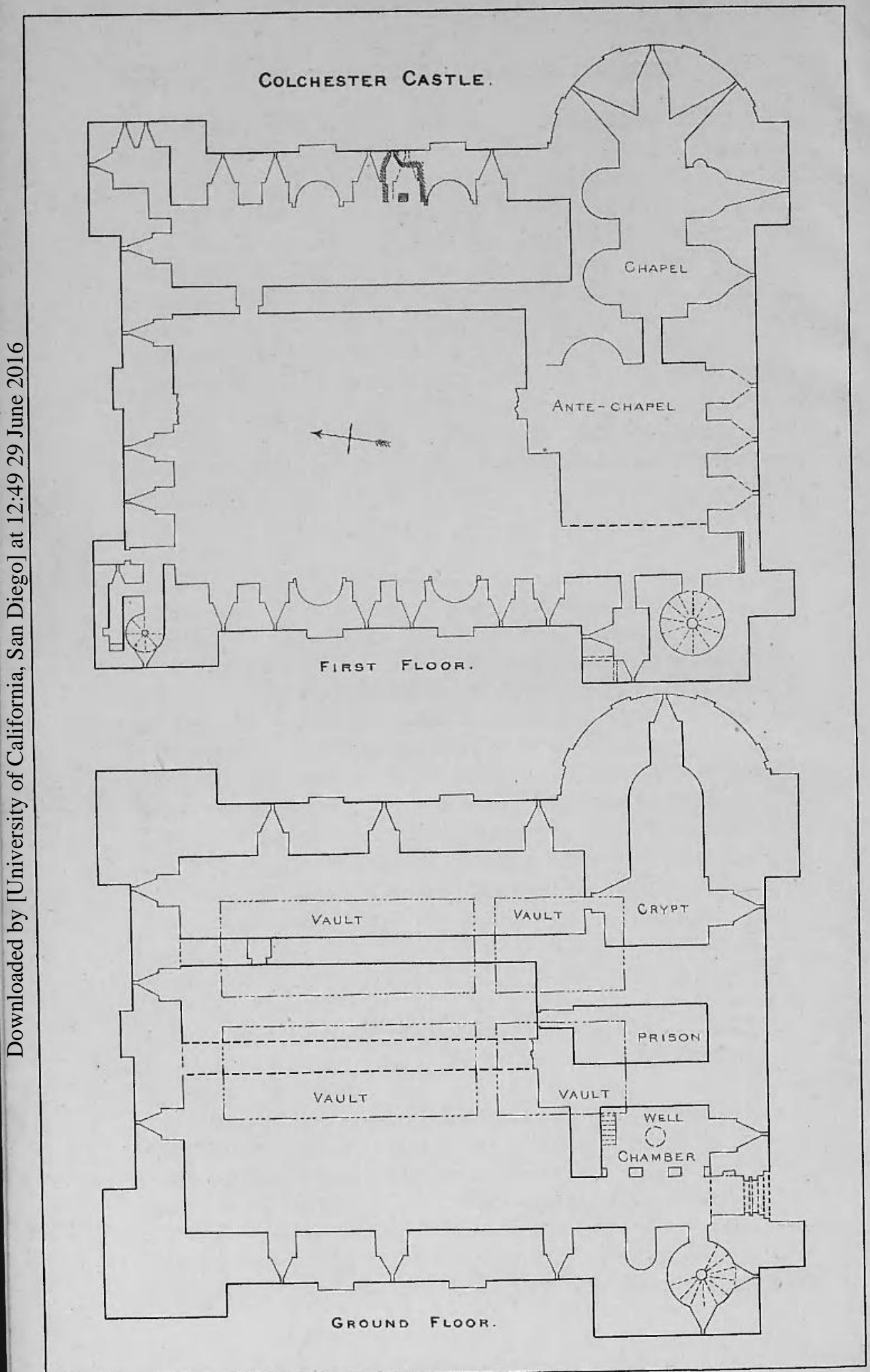


who gave it in fee, in 1629, to Hay, Earl of Carlisle. The immense thickness of its wall and its central position led to its being held for Charles in the war with the Parliament, when its commander was Sir Charles Lucas, a member of a local royalist family, and the descendant of the grantee of St. John's Abbey lands. The siege and capture by Fairfax and the subsequent military executions are well known matters of history. The enceinte wall was probably then pulled down, and the castle rendered untenable. Soon afterwards what remained was sold to a person named Wheeley, who attempted to pull down the keep, with only partial success. Since then it has been in the Gray and Round families, and has been properly cared for, as indeed it still is.

\section{DESCRIPTION.}

The keep, the only remaining portion of the castle, is a peculiar and, in many respects, a very remarkable structure; remarkable for the unusually large area which it covers; for its want, even in its original state, of a proportionate height; for the arrangement and design of its parts and details ; for the materials of which it is composed; and for the workmanship by which they are put together. Not only is its origin disputed, but the purpose for which it was constructed is still the subject of a controversy, the settlement of which can only be effected by the internal evidence afforded by the building itself, the minute details of which possess on that account peculiar interest.

It is in plan rectangular, and, at its interior ground level, which is also, very nearly, that of the top of its spreading plinth, it measures, exclusive of its six projections, 152 feet north and south, by 111 feet east and west, and with its projections 171 feet by 146 feet. The two northern angles are capped by two rectangular turrets, of which the north-west is on the west face 29 feet broad with 8 feet projection, and on the north face 30 feet with 8 feet projection. The north-east turret is 29 feet on the east and 27 feet on the north face, with projections of 8 feet. The south-west turret projects from the south end of the west wall 14 feet, and has a breadth of 40 feet. The south-east turret occupies a similar position on the 
east front, but is in plan a half circle with a diameter or breadth of 50 feet, and a projection of 25 feet. The south wall has a buttress on its face at each end. That at the east end is 20 feet broad by 8 feet projection, and that at the west end 12 feet broad by 8 feet projection. This latter protects the entrance.

On the longer or east and west faces are two intermediate pilasters 8 feet broad by a foot projection, and on the north face one pilaster 8 feet broad by 18 inches projection. Against the semi-circular turret are placed four pilasters 4 feet 10 inches broad by a foot projection, and at the springing two half pilasters 2 feet 5 inches broad. Turrets, buttresses, and pilasters, with one exception, rise to the present summit unbroken by set off or string course. The exception is the north-west turret which, at the first floor level, is reduced on its north face from 30 to 24 feet, the six feet forming a shelf or landing for an entrance door. The plinth is carried round the building and capped by a plain chamfer. Below this the walls spread laterally inside and outside, until at a depth of some 30 feet they have a base of about 30 feet. The part above ground was cased with ashlar which has been stripped off. This excessive depth and breadth of foundation is very unusual. The two northern turrets are solid to the first floor level, as are the two southern buttresses, one indeed being solid throughout. The south-west turret contains a well-staircase which ascends from the basement to the summit. The south-east turret contains a crypt at its ground level.

The space within the walls, measuring 126 feet by 87 feet, was unequally subdivided. A portion, in width from 36 to 40 feet broad, was walled off at the south-end and occupied as an entrance passage, a well chamber, a prison vault, and the crypt beneath the chapel. The space northwards was again sub-divided into an east, west, and middle compartment by two walls running north and south. The eastern compartment, 91 feet by 22 feet, was aired rather than lighted by three loops in the east and one in the north wall. One of these loops was in the last century converted into a door, but has since been walled up. The central loop is now a door. In the south end a small doorway leads into the crypt. 
This compartment was entered by a doorway in the cross wall, 3 feet 9 inches broad, but having a rebate for a door. The wall is 7 feet thick. The middle compartment was 80 feet long by 15 feet broad, but its western wall, which was 7 feet thick, was removed, it is said, in 1683 . A trace of it remains at the south end, and at the north end a projection in the wall shews that the door of comcommunication was at that end. This compartment has a single loop in its north end, and in its south end a doorway leading into the prison vault.

The western or larger compartment from which the others were entered was 90 feet long by 36 feet broad. It had a loop in its north end, and three in its west side. In its south wall was probably the inner doorway corresponding to the main entrance. It is said that there exists a pit or drain beneath the floor of this chamber, a sewer from which, of Roman construction, passes westward through the wall towards the river. The loops throughout this ground floor are of one pattern. They are roundheaded, six inches wide, in the end of a splayed recess which opens by a set-off into a flat-sided recess seven feet wide and three feet six inches deep. These recesses are round-headed, and rise from the floor-level about twelve feet. The recess and the arched head are constructed mainly of tiles. The set-off or reveal is of ashlar. All the arches throughout, of both doors and recesses, are round-headed. The three compartments were covered in with whole timber joists supporting the floor of the upper chamber. The ground floor was about fifteen feet high, and, save the vault and crypt, seems to have been intended for stores.

The main entrance is on this floor, at the west-end of the south side. A doorway of seven feet seven inches opening was flanked on each side by two niched columns with plain bases and capitals, with stiff foliage of Norman character. Above the capitals is a plain chamfered abacus. The head is composed of three members, each a bold roll or bead. The two inner members spring from above the capitals, the outer member, with a dripstone worked in two bands of half circles, springs from the abacus alone. The abacus is stopped within the portal by a square groove for a portcullis, probably of iron, behind which is a rebate 
for a door with a hole for a stout wooden bar. Five or six steps, now concealed or gone, led up to this doorway, nor are there any traces of a drawbridge. Within the portal, in the wall, here fourteen feet thick, on the left, is a small round-headed niche, the flat sides and back of which are carved with low bas-reliefs of certain bishops and saints, including St. Christopher. They are fairly executed, and probably the work of some ingenious porter.

The door opens into a lobby or entrance passage 12 feet broad by 36 feet long. The right hand wall is an open arcade, modern, but probably representing an older wall, shutting off the well chamber. The south end is now open but was crossed by a wall 10 feet thick, which no doubt contained the inner door leading into the great ground floor chamber. On the left is first the door of the great staircase, then a niche 8 feet broad and 9 feet high and 7 feet deep, and semi-domed. A short passage, vaulted and groined, leads into the great staircase, a cylinder 16 feet diameter, with a newel of 2 feet. It has loops to the south and west, and forty-seven steps lead to the present summit. At the twenty-third step a passage with three steps branches off to the first floor.

The well chamber, 15 feet by 26 feet contains the well, now closed by a pump. It is 5 feet diameter and 65 feet deep, and was lined with ashlar, of which the upper part has been stripped off. The well was discovered in the last century. It is said that in it was observed a lateral culvert, intended as a waste pipe to carry off any overflow that might otherwise injure the foundations. In the south wall was a recess 8 feet broad and 7 feet deep, round-headed and semi-domed, now a window. Probably the buckets stood in it. Here also a modern stair descends to the vaults. The well chamber is not vaulted. Next east, separated by a wall 9 feet thick, is the prison; this is a barrel-vaulted chamber 15 feet by 30 feet, entered from the middle compartment by a doorway of 3 feet opening; it supports the ante-chapel. East again of this vault a wall, 13 feet thick, divides it from the crypt. The western part of the crypt, the cross limb of the $T$, is rectangular, 14 feet by 28 feet, vaulted and groined, and entered from the eastern compartment; it has a loop in its south wall. The stem of the $T$ is the 
crypt proper, 31 feet long by 14 feet broad and 14 feet high to the crown of its barrel vault. Its east end is semi-circular and semi-domed. A lonp in the centre of the apse has been converted into a window. In this crypt is said to be a drain falling southwards towards the river. This completes the account of the ground floor.

From the staircase a door opens into the lobby above the entrance passage, and which was probably of the same size. At present the east and north walls are modern. The south end of this lobby is occupied by a flat-sided and flat-backed recess, 10 feet broad, 10 feet deep, and about 12 feet high, which has a chink or chase in its floor for the passage of the portcullis. As the recess is wider than the grate there are no lateral grooves. Above is a cavity where was inserted the ring or hook whence the grate was suspended. On the left of the staircase door is a smaller door which opens into a garderobe which shares the turret with the staircase. It is 15 feet 6 inches long by 10 feet 4 inches broad, barrel-vaulted, with loops to the west and north, and beneath each a seat and a shoot in the wall. The loops have been enlarged into windows, and the chamber is used as a record room. Outside, in the north wall of the turret, close to its junction with the curtain is a bold deep bracket, composed of seven stones and a tile, at the top projecting about a foot, which may have supported the shaft of a garderobe from the battlements. or may have been connected with some sort of bretasche or timber erection. It use is not clear. The east wall of the lobby divides it from the modern library which stands over the ancient antechapel, and was probably the principal private apartment in the keep. It had three recesses, no doubt with loops, in its south walls. Two are now windows, and one a fire-place. Outside this chamber, to the north, is a modern corridor, the space of which was apparently a part of the antechapel. In its east wall is a round-backed niche 10 feet broad, through which a passage has been broken, most injudiciously, into the chapel. From the antechapel a lofty round-headed doorway opened into the west end of the chapel.

The chapel is composed of a nave and apse, and of four 
lateral recesses or side chapels. It is in length 45 feet and in breadth 15 feet, and 17 feet 6 inches high to the crown of its barrel vault. The apse is semi-circular and semi-domed, of the same height with the nave. The westernmost pair of recesses are 14 feet wide and 12 feet deep, with semi-domed ends. The eastern pair are 11 feet wide and 11 feet and 14 feet deep, and both semi-domed. In the east wall of the south recess is a niche as for a side altar. The lateral vaults are accommodated to the main vault. The groins or lines of intersection are plain. The apse has a central recess, now a window, and two lateral smaller recesses with loops, unaltered. As the walls are everywhere very thick and the five original apertures could not have exceeded eight inches, the chapel must have been more than usually dark. It contains no ornamentation of any kind, not even an abacus or plinth. The masonry appears to be rubble of a very ordinary character. It is thickly plastered. This is a very curious and rare example of a castle chapel.

The first floor, north of the chapel and the entrance lobby, is divided into a larger west and a smaller east chamber. The eastern chamber is 21 feet by 88 feet, the western 61 feet by 100 feet, the increase of size over the lower area being due to a slight reduction in the thickness of the walls.

The eastern chamber is entered from the western by a doorway in the dividing wall. In its north end is a loop, in its east wall two fire-places; north of the one are two loops and one south of the other; between them is a fourth loop and a mural garderobe. This chamber, 3 feet 6 inches by 9 feet 3 inches, has an eastern recess 3 feet wide, and in it a small loop beneath which is the seat, and a shoot opening in the wall. There are two doors opening from the main chamber 3 feet 3 inches apart. It is probable that the chamber was divided by a partition of wood, so that there was a fire-place in each room, and the garderobe was common to the two with a door opening from each. The north-east turret here contains a vaulted chamber, 13 feet by 10 feet and 16 feet high. It has one loop to the north and two to the east, now broken into one. In the west wall is an indication either of a fire- 
place never completed, or of one walled up. This was probably a bedchamber.

The western chamber may possibly have been subdivided like the lower floor by a wall raised upon that now removed; and an unequal space between the loops in its north wall fuvour this view. More probably, however, the wall was not so raised, and the irregular space may be caused by a wish to keep the loops clear of the external pilaster. The chamber, supposing it to have been of the full breadth, had four loops in the north wall, and in the west wall two fire-places, having two loops between and two beyond each, six in all. - The fire-places are spacious, round-headed, with rounded backs set with tiles on edge in herring-bone pattern. They stand in a broad pilaster of a foot projection, and are quite plain. They are of tile, of one pattern throughout, and at a height of about 14 feet the flue is stopped, and divides into two branches which open in the face of the wall, one on each side of the pilaster, in the hollow angle, as at Rochester. These fire-places do not seem to have had any hood. Over one of them is a sort of weather moulding of tile, which looks as though part of a hood, such as is still seen over the west door of St. Botolph's Church. There is, however, a second fragment on the jamb of the fire-place, which could not be part of a hood. These are probably the remains of the weather mouldings of the roofs of cottages built within the area of the keep after the whole was gutted and laid open. The loops of this floor, like these below, are of one pattern. A recess, 7 feet wide, flat-sided and round-headed, commences at the floor level and rises about 14 feet. At a depth of 3 feet 6 inches is a rebate or reveal, from which commences a splayed recess, ending in a loop eight inches wide.

In the north wall, at its west end, is a plain doorway and a recess corresponding to a doorway in the outside of the wall which opened upon the shelf already mentioned as in the east face of the north-west turret. This shoulder formed a landing, 6 feet by 8 feet, whence a staircase descended by a face of the wall to the ground. The walls shew where the staircase was let into it by the dis continuance of the regular coursing, but this also shews the staircase to have been an afterthought. The original 
staircase was probably of wood. The door has evidently been walled up from an early period. In the west side of this doorway is a smaller lateral doorway opening into a groined lobby, which leads into a staircase and a garderobe, which occupy the north-west turret. The garderobe is 7 feet by 2 feet, with a loop to the east and the seat and drain to the west, and in the north wall a recess as for a lamp. A few feet south of the seat and its shoot a second shoot is seen in the outer wall. This probably belonged to a garderobe in the battlements, now gone. The staircase is a well, 6 feet diameter, of which twentyfour steps remain. It evidently led from the first floor level to the summit. The fragment of the turret seems to shew that the original height of the wall was about 32 to 36 feet. This and the main staircase are cut short by the removal of the upper 5 feet or 6 feet of the wall. They open upon the present top of the wall, which has been levelled, and a slight battlement and rear wall built to make the walk safe. There does not seem to have been a second floor.

Some years ago, about 1683 , the then proprietor of the Colchester, ignominiously known as having removed the upper part of the walls and gutted the interior of the building, discovered that a part of the ground floor rested upon vaults. These he opened and examined, and they are still accessible. The vaults are two in number, built side by side, each 22 feet wide and 96 feet long. They are crossed by a wall 6 feet thick, and thus formed into two vaults of 60 feet and two of 30 feet. The wall between them is 8 feet thick. When discovered they were full of earth, so full that it was evident the contents of the foundations had been heaped and used as a centring, the arch being turned upon the earth. Of one vault the roof is flat, held up by the mere cohesion of the masonry. These vaults had no original entrance and were evidently works of construction only, not intended to be used. Several breaches were made so that one vault can be entered from another, and a breach was also made in the north wall of the keep below the exterior ground level, through which a good deal of this soil was removed, and thus the cavities admit of a partial examination. The masonry is wholly rude rubble, composed of large pebbles 
and boulders and fragments of stone, uncoursed, and with a very free use of mortar. The vaults are described as pointed, but the excessive rudeness of the work, and the nature of the centring would account for any irregularity in the figure of the arches. To the eye they appear rudely semi-circular. That these vaults are of the date of the keep is evident from their relations to the other walls, part of which rest upon them. The present entrance is in the floor of the well chamber.

For some reason, possibly from an apprehension of defective foundation in a wet sandy soil, it seems to have been thought necessary to take extraordinary precautions against an unequal settlement of the parts of the keep. Hence probably the extensive area, the low altitude of the walls, and the excessive breadth of their foundations. Hence, also, probably, the decision to elevate the floor of the interior above the exterior ground, by the use of vaulting. If such was the cause of these unusual precautions, the result has been perfectly successful, for there is no mark of subsidence anywhere to be seen.

Although a main entrance at the ground floor level is by no means unknown in Norman keeps, and is found at Carlisle, Ludlow, and Bamborough, it was not usual, and an examination of the present entrance at Colchester leads to the conclusion that it was not originally so here. It is evident not only that the present ornate doorway is an insertion, but that the outer part of the wall above has also been taken down for a considerable height, and clumsily rebuilt. This was done to allow of the insertion of a portcullis. Without this it would have been sufficient to remove the lower masonry only, but the grate required head room when raised, and to gain this a more extensive alteration was necessary. Immediately above the drip stone are a few courses of ashlar, derived no, doubt, from the old work, but above this the wall is of very inferior uncoursed rubble, very different from the regular courses of stone and tile seen in the wall on either side. When the outer door case was inserted the wall within was also lined with ashlar, and the ring stones of the inner arch and of the entrances to the great staircase were also so cased. Above, the recess into which the portcullis was lifted is of tile and evidently original, but the floor with the aperture or chase, and the flat back of the recess are 
later. In all probability there was originally a recess with perhaps a loop where the great doorway now is, and there was certainly a recess above, with probably a loop also. When this door was opened, in the latest Norman period, the original entrance on the first floor, in the north front, was probably walled up, as it still remains. It has been suggested that the great doorway replaced a postern, but posterns in Norman keeps were very unusual indeed, especially at the ground level, and there seems no reason for supposing one here. Probably when the keep was constructed there was no enceinte wall, but when this was built, the keep became far more secure, and as it was convenient to have an entrance from the town side, the change was made.

There is something to be said for the pertinacity with which this keep has been asserted to be a Roman building. Not only is its design peculiar, but this is also the case with the material employed, and in some degree with the workmanship. The walls, though cased with ashlar on the plinth, and though ashlar is largely employed in the quoins up to the first floor, contain great quantities of the large square thick tile so characteristic of Roman work. Moreover, these tiles are mostly whole, as though they had not been employed in an older building, and they are laid in bonding or chain courses, single, double, triple, and even in four courses, with intervening bands of cement stone in small rudely squared blocks. Sometimes the tiles are laid on edge, sometimes slightly inclined, with here and there a tendency to herring-bone, and the greater part of the interior dividing wall is regular herring-bone, and a very fine example of it. Most of the recesses within the walls were not originally looped, and are round-backed and semi-domed, which is unusual in Norman keeps. Outside the building, high up in the walls, are traces of a number of apertures or perhaps only sunken spaces, about 2 feet 6 inches square. One of these is shewn in an early drawing as containing a sun-dial, no doubt an insertion. It has been supposed that these represent tablets with an inscription, but there is no evidence for this. What they were for it is difficult even to guess.

All these features, and some others not actually present, have been adduced to justify the opinions of General Roy, King, and others, in favour of the Roman origin of the 
building, which is asserted to have been constructed to contain and guard the shrine of a Pagan deity, and afterwards to have been converted by the Normans into a fortress. Such conversions of Roman buildings into mediæval fortresses were, no doubt, common enough in Italy and France, and not unknown in England, as at Pevensey and Porchester, but nevertheless there scarcely seems ground for supposing this building to be Roman, or other than a Norman keep.

The combination of the rectangular plan with angle turrets and intermediate pilasters of slight projection is distinctly and peculiarly Norman. As to the unusual dimensions of the building, in size and height Norman keeps varied considerably, from Clitheroe and Goderich up to Norwich or London. The projection of the turrets also varies from mere pilasters as at Bowes and Scarborough to regular turrets as at Dover and Kenilworth. The halfround projection and the chapel within are indeed rare, being confined to Colchester and London, but no one conversant with the smaller Norman churches could hesitate to class these among them. The spreading plinth is also a Norman feature, and is seen at Norham and Kenil. worth. Thick and solid walls at the ground floor are also common. One of the most usual Norman arrangements was to place at one angle a well-staircase communicating with each floor and with the roof, while at another angle was a similar staircase commencing at the first floor.

The Norman entrance, though sometimes on the ground floor was more usually, as originally here, on the first floor. Neither was it always protected by a fore-building. Neither Goderich, Clitheroe, nor Chester were so protected. The well in Norman keeps, though often in the wall, was also found in other situations. At Norwich and Castle Rising it was within the area, and at Bamborough. Mural chambers, especially for garderobes, are common in Norman keeps, especially at the first floor level. Here are three, and a larger chamber, besides the chapel and antechapel. The shoots of Norman garderobes usually open on the face of the wall, the lower stone projecting a little to keep the filth clear of it, as at Ludlow and Carlisle. The opening of the flues of the fire-places upon the face of the wall, close to a pilaster, is a purely Norman device. The use of loops on the first floor, though with large splayed VOL, XXXIX. 
recesses, is:also Norman, and a part of the jealous system that pervaded their keeps. Usually it was only at the second floor that the loops became windows. In Norman keeps the floors were almost always of timber, the joists being supported, when necessary, by post or props, as seen at this day in the Tower of London.

As to material the use of new and clear and unbroken tiles by no means shews a work to be Roman. Those of St. Botolph's Priory Church were evidently never used before. The only conclusion is that they were manufactured in imitation of those introduced by the Romans. Neither is the mortar that usually described as of Roman composition. It is decidedly white or light in colour, with a great preponderance of sand, so much so as in some parts to have prevented its setting. Where the mortar is in masses it may contain fragments of tile or stone, but there is no trace of pounded brick in its composition. It is generally ill-mixed, and contains large fragments of sea shells. The putlog holes in size and position are such as are usually observed in buildings of the eleventh and twelfth centuries, though probably not confined to them. The soffits of the vaulting of the staircase and mural chambers everywhere are impressed deeply with the figure of the boards used as centring, or what is called technically lagging. The carpenters' work in Norman keeps seems to have been very rudely performed, and the rough boards were spread over thickly with mortar to bring them to a surface. This is well seen at Colchester.

Taking all these features into consideration there ought to be little doubt that Colchester keep is a Norman structure, built probably about the close of the eleventh century, by one of the sons of Hubert de Rie

The keep is the only part of Colchester Castle now standing. The wall enceinte has long been removed, probably about 1650 , but its general line to the east, north, and west is indicated by three earth banks. To the south the ground has been levelled. The entrance from the town was on this side. This was the main gate, but there was also a second. The area thus enclosed appears to have been rather above three acres. Various Roman remains have been discovered within and about this area. 